Article

\title{
From Access to Documents to Consumption of Information: The European Commission Transparency Policy for the TTIP Negotiations
}

\author{
Evelyn Coremans
}

Leuven International and European Studies, KU Leuven, 3000 Leuven, Belgium; E-Mail: evelyn.coremans@kuleuven.be

Submitted: 4 May 2017 | Accepted: 10 July 2017 | Published: 25 September 2017

\begin{abstract}
To increase transparency of the Transatlantic Trade and Investment Partnership (TTIP) negotiations, the European Commission has reformed existing information sharing systems for trade policy. The Commission has moved from a strategy of providing transparency in the form of access to documents to one of access to information, geared specifically towards enhancing consumption of the available information. In both public and institutional transparency policy, the width of the target audience and the depth of the information have increased, and the manner of provision has shifted from reactive to proactive provision of information. As a result, the TTIP is now being coined as the most transparent trade negotiation ever in the EU's history and a pilot project for transparency policy in future trade negotiations. The article adopts a supplycentred perspective to explain a transparency policy that goes beyond the legal minimum imposed by formal requirements. It relies on interview data of the changes brought about in inter-institutional relations since 2014, basic quantitative and qualitative analysis of document material, and a five-month participatory observation by the author in the secretariat of the European Parliament's Committee on International Trade.
\end{abstract}

\section{Keywords}

access to documents; common commercial policy; European Commission; European Parliament; information; negotiation; trade; transparency; TTIP

\section{Issue}

This article is part of the issue "EU Institutional Politics of Secrecy and Transparency in Foreign Affairs", edited by Vigjilenca Abazi and Johan Adriaensen (Maastricht University, The Netherlands).

(C) 2017 by the author; licensee Cogitatio (Lisbon, Portugal). This article is licensed under a Creative Commons Attribution 4.0 International License (CC BY).

\section{Introduction}

Since 2014, the European Commission (henceforth Commission) has been reforming existing information sharing systems to increase transparency of the negotiations for the Transatlantic Trade and Investment Partnership (TTIP) (Cremona, 2015). The Commission has also explicitly stated that these practices will become the new rationale for future trade negotiations (European Commission, 2015b). Literature on EU trade policy assesses transparency from the perspective of the demandside, either based on Access to Documents legislationpublic transparency-or by analysing Inter-Institutional Agreements-institutional transparency (Devuyst, 2013; Hillebrandt \& Abazi, 2015; Jančić, 2016; Kleimann, 2011; Meissner, 2016; see also Gheyle \& De Ville, 2017; Rosén \&
Stie, 2017, in this issue). So far there has not been any comprehensive effort to map and analyse changes in transparency policy from the perspective of the supply-sidei.e. the Commission. Hence, a supply-centred analysis of the Commission's motivations for and methods of providing transparency offers a novel perspective to this debate.

This article gives an overview of the changes in the Commission's transparency regime for trade policy since the start of the TTIP negotiations mid-2013 until the natural pause after the United States (US) elections in November 2016. The period is inductively generated from the case study, as the end date is chosen at a time where the transparency practices are sufficiently consolidated and not much further change is expected. The analysis will discuss the changes in public transparency policy, as well as changes in institutional transparency and document- 
and information-sharing at the EU level. ${ }^{1}$ For the latter, the Commission-European Parliament (henceforth Parliament) axis will be the primary focus, as it is here that most post-TTIP innovation has taken place. ${ }^{2}$ The analysis shows how the provision of transparency can generate procedural changes and impact inter-institutional relationships (see also Abazi \& Adriaensen, 2017, in this issue). In addition, this study contributes to the debate around accountability and democratic deficit in EU policy making, as it shows the importance of qualitative changes for the consumption of information.

The data consists of interview material and participatory observation by the author in the secretariat of the Parliamentary Committee for International Trade (henceforth INTA). ${ }^{3}$ This is supplemented by an analysis of document material consisting of memos, guidelines, or training material for staff on record creation and keeping, and on the processing of access to information requests; documents that refer to creation and keeping of agendas, lists of meetings, minutes of meetings, lists of participants in meetings, and documents justifying decisions; and institutional documents containing rules and procedures for inter-institutional information-sharing. The following section gives an overview of the existing scholarly work about transparency in the EU and identifies where this article may provide additional insights. The third section introduces the conceptual framework guiding the empirical analysis, which is set out in the fourth section. The conclusion reflects on these findings and proposes new questions for further study.

\section{State of the Art}

Literature on transparency in the EU has predominantly portrayed the Commission and the Council of Ministers (henceforth Council)-and more recently the European Council-as reluctant to provide the requested information out of concern for 'space to think' and efficiency of the decision-making process (Curtin, 2014; Hillebrandt \& Novak, 2016). The focus has predominantly been on Council proceedings, driven by the reforms introduced by Regulation 1049/2001 on access to documents and a perceived power shift towards the Council and the European Council in EU politics (Curtin, 2014). Several studies have analysed the institutional drivers of Council transparency policies (Bjurulf \& Elgström, 2004; Hillebrandt, Curtin, \& Meijer, 2014). In addition, scholars have assessed the impact of changes in Council transparency policies on its inter-institutional bargaining power. Premised on informational asymmetry arising from different degrees of transparency, there may be a negative correlation between the level of transparency an institution is required to provide and that institution's leverage in inter-institutional negotiations (Hillebrandt \& Novak, 2016; Meijer, 2013). ${ }^{4}$

More specific literature on EU trade policy assesses transparency from the perspective of the demandside, either based on Access to Documents legislationpublic transparency-or by analysing Inter-Institutional Agreements-institutional transparency. These studies tend to place the Commission on the defensive and at the losing end of the spectrum, reluctantly forced to provide more transparency by an increasingly assertive public opinion and powerful Parliament (Devuyst, 2013; Hillebrandt \& Abazi, 2015; Jančić, 2016; Kleimann, 2011; Meissner, 2016; Rosén \& Stie, 2017, this issue).

Yet both strands of literature remain silent about what can explain a transparency policy that goes beyond the legal minimum imposed by Treaty and case law or by formal requirements enacted in institutional agreements (like the one that we have seen developing in the case of TTIP). This article contributes to the literature on transparency in EU external trade policy from a supplycentred perspective: why does the Commission to provide transparency if it might reduce its bargaining power? And more specifically, why does it go beyond the legally required minimum when doing so?

Previous research on inter-institutional cooperation between Commission and Council in EU trade negotiations has found that the Commission may on its own initiative choose to provide institutional transparency and thereby balance informational asymmetries to preempt negotiation failure at the ratification stage (Coremans \& Kerremans, 2017). With the Parliament as a new powerful player in external trade policy since 2009, I expect the Commission as the external negotiator to attach more importance to coordination with the Parliament for international negotiations, compared to the pre-Lisbon situation-as the number and power of internal stakeholders has increased (Winham, 1979). Taking into account previous experience with failed ratification in the case of the Anti-Counterfeiting Trade Agreement, such coordination could prove vital for the Commission to anticipate the reaction of Parliament to the negotiation outcome: 'since the EP might kill the agreement in the end, listening to their demands is common sense'

\footnotetext{
${ }^{1}$ The analysis refrains from detailing the legislative framework for transparency policy and inter-institutional coordination for international agreements, as this has been done elsewhere (Devuyst, 2013, 2015; European Parliament, 2015a; Leino, 2014).

2 Relations between the Commission and the Council on trade negotiations have not changed significantly with the TTIP negotiations, and will therefore not be covered in this article (See Coremans \& Kerremans, 2017).

${ }^{3} 9$ interviews were conducted between November 2015 and May 2016 with Commission, Council, and Parliament officials. The respondents were selected based on their function within the institutions, which means officials from Directorate-General for Trade within the Commission (DG Trade), Parliament officials involved the INTA Committee, and officials from the Council's Directorate for Trade. In terms of substance, the interviews covered pre-Lisbon and current working practices regarding the negotiation of multi- and bilateral trade agreements, as well as the current transparency policy. Answers were cross-referenced between officials of different institutions. The participatory observation consisted of an unpaid Schuman traineeship in the INTA secretariat from October 2016 to February 2017. Clarifications and factual corrections were obtained via follow-up contacts with respondents.

${ }^{4}$ Still the question remains in how far formal transparency requirements reflect the true level of informational asymmetry between institutions (Adriaensen \& Coremans, 2017; Coremans \& Kerremans, 2017).
} 
(Rosén, 2016, p. 9, emphasis original; see also Devuyst, 2013; Dür \& Mateo, 2014; Egeberg, Gornitzka, \& Trondal, 2014; Eibauer, 2012). Hence, providing transparency and thereby reducing information asymmetry might actually be beneficial for the Commission in terms of enhancing its external negotiation effectiveness-i.e. concluding an international trade agreement, instead of compromising the Commission's inter-institutional bargaining power. It can also explain why the Commission would go beyond the legally required minimum when exchanging information with the Parliament, as such engagement fosters reciprocity (Coremans \& Kerremans, 2017).

By adopting a Commission-centred perspective, this article also addresses two other neglected areas in the study of transparency and EU decision-making. First, while a few studies of Commission-Parliament relations have covered daily interaction patterns between these two institutions and reasons explaining such patterns, empirical research on this inter-institutional relationship is still largely absent (Egeberg et al., 2014; Rosén, 2016). In addition, most struggles in EU trade policy are about access to information and inclusion in decision-making (Ripoll Servent \& Busby, 2013). Yet the dominant focus in EU trade policy research has been on actors' influence on the final policy outcome, while the study of procedural rules and norms has generally remained merely a means to an end. By exploring inter-institutional coordination procedures between Commission and Parliament for trade negotiations, this article aims to contribute to this empirical quest.

Second, this article analyses the qualitative aspect of transparency policies. It provides insight into the type of information provided, as well as the manner of provision and the targeted audience. This is warranted as the number of published documents does not automatically reflect the actual amount of information available (Cross, 2014; Curtin \& Meijer, 2006). A purely quantitative perspective does not allow for drawing conclusions on democratic legitimacy resulting from transparency, as this would assume an 'automatic link' between the amount of information available on the one hand, and legitimacy of decision-making outcomes and public perception of transparency on the other (Brandsma, 2012; De Fine Licht, 2014; Naurin, 2007). For instance, in searching a balance between the need for democratic scrutiny and need for secrecy, giving 'MEPs privileged access to documents [can] alleviate accusations of a democratic deficit while accommodating the need for secrecy' (Abazi, 2016; see also Rosén \& Stie, 2017, in this issue). Differentiating between different types and dimensions of transparency allows for assessing these types of qualitative changes.

\section{Three Dimensions of Transparency}

Critique of insufficiently transparent negotiations indicates a lack of information about the ongoing discussions between negotiating actors (Abazi \& Tauschinsky, 2015; Meijer, 2015). Transparency is therefore defined as 'the availability of [regime relevant] information about an actor that allows other actors to monitor the workings or performance of the first actor' (Meijer, 2013; Mitchell, 1998). Regime relevant information also encompasses information about the process through which a decision is made. Qualitative changes in the level of transparency can happen on three dimensions: the width, depth, and manner of provision of information.

The width of the provided information refers to the number of people that has access to the information. It can be conceptualised as a continuum of concentric circles varying from institutional transparency to public transparency. In other words, public transparency is understood as a further stage after widening institutional transparency. Institutional transparency refers to information exchange between institutional actors, whereas public transparency is conceived in the relationship between the institutions and external actors (Ostry, 2004). Institutional and public transparency are linked in the sense that extending public transparency usually automatically entails extension of institutional transparency: if information is public, institutional actors can access it as well. Of course, if the concerned information was already subject to institutional transparency, there will be no perceived change on the institutional level after introducing public access. Yet despite this overlap, institutional and public transparency are qualitatively quite distinct. Inter-institutional document exchange and interaction patterns will naturally differ from those between an institution and the broader public, and institutional transparency will remain more protected and controllable compared to public transparency. Therefore, the empirical discussion addresses institutional and public transparency separately to allow for a more clearcut depiction of the changes in the Commission's transparency policy. These differences however, do not preclude the possibility of similar patterns in terms of expanding width and depth, and changes in the manner of provision of information.

The depth of transparency refers to the type of information provided. Transparency in existence points to information about the format of certain practices, whereas transparency in substance relates to the availability of information about the content of those practices (Cross \& Bølstad, 2015). ${ }^{5}$ The former would be achieved by publishing a notice that a particular meeting took or will take place, whereas the latter would require the availability of meeting agenda's or minutes containing information about the actual content of that meeting. Increasing depth of transparency is also reflected in the amount of detail and degree of political sensitivity that is contained in the information. The dimension of depth is analysed by assessing which documents are made available and what kind of written information they contain, as well as the

\footnotetext{
${ }^{5}$ It logically follows that the precondition for requesting and accessing information on the content of the practice is knowing that such information exists in distributable form. These dimensions have also been referred to as deep and shallow secrecy, respectively (Pozen, 2010).
} 
extent of information that is provided orally in briefings and meetings.

The manner of provision pertains to the way information is provided by one actor to other actors. Reactive transparency is the provision of information in reaction to a specific request. Proactive transparency comprises information that is made available regardless of any such specific demand-and thus on the provider's own initiative (European Ombudsman, 2015a; Meijer, Curtin, \& Hillebrandt, 2012). Proactive transparency is geared towards enhancing the consumption of information by providing additional information that goes beyond responding to individual access to documents requests. The manner of provision is assessed empirically by looking at whether the Commission takes the initiative for sharing documents, organising information briefings, and foreseeing room for questions and answers in meetings.

Any shift towards proactive, substantive and/or widened institutional and public transparency is defined as an increase in transparency. The following section will address each of these three dimensions in the case of the Commission's transparency policy for the TTIP. The discussion on institutional transparency only covers the Commission-Parliament relations, as it is here that the TTIP has been most transformative. Relations between the Commission and the Council are not discussed because stable working relationships were already in place prior to the TTIP negotiations (Coremans \& Kerremans, 2017). The findings rely on interviews with officials from the relevant institutions, participatory observation by the author in the secretariat of the INTA Committee, and document analysis.

\section{Results}

The Commission as the EU's external negotiator for trade agreements is the primary institutional actor responsible for distributing information on trade negotiations. Taking instructions from Council (formally) and Parliament (informally), it is responsible for formulating a common position and defending it towards the negotiating partner, as well as providing feedback on those external negotiations afterwards. ${ }^{6}$ More specifically, this responsibility lies with the DG Trade headed by the Commissioner for Trade (at the time of writing Ms. Cecilia Malmström, who succeeded Mr. Karel De Gucht in November 2014). Decisions about which transparency policy to follow are made in DG Trade Directorate A (Resources, Information and Policy Coordination), in coordination with the Commissioner's cabinet (Mungengová, 2016). This section will provide an overview of the main changes in the transparency policy for TTIP on the dimensions of width, depth and manner of provision of information.

\subsection{Public Transparency}

At the outset of the negotiations, there was no mention of making public any negotiation documents produced in the context of the TTIP negotiations-with the possible exception of EU position papers (European Commission, 2013). By spring 2014, a lack of information on the content of the negotiations fuelled speculation in public opinion about what was being negotiated (Agence Europe, 2014a). By March 2014, DG Trade published a communication in which it articulated how negotiations are conducted and which actors are involved in EU-level decision-making on TTIP (European Commission, 2014a). This can be classified as a strategy of providing transparency in existence.

In addition to this communication, DG Trade published a limited number of negotiation texts online (European Commission, 2014c). Following repeated requests from the Commission and after an own-initiative inquiry by the European Ombudsman, the Council finally released the TTIP negotiating mandate in October 2014the first of its kind to be made public while negotiations were still ongoing (Council of the EU, 2014; European Ombudsman, 2015b). ${ }^{7}$ Both initiatives marked the start of a paradigm shift from a strategy of transparency in existence early 2014, towards transparency in substance over the course of the latter half of 2014 and throughout 2015.

In November 2014, DG Trade formulated a more precise strategy for the provision of substantive transparency in TTIP negotiations, with the intention of demystifying misunderstandings about their content (Agence Europe, 2014b; Mungengová, 2016). This communication introduced a strategy of elaborating transparency in substance and proactive provision of information by increasing the number of EU position papers made publicly available and reviewing the manner of classification of information. From December 2014, DG Trade also started publishing lists of all unclassified TTIP documents it shares with Council and Parliament (European Commission, 2014b, 2015d, 2016b).

In January 2015, DG Trade started publishing legal texts or 'textual proposals', which contained more specific information regarding wording and binding commitments compared to the previously available EU position papers (Agence Europe, 2015a). Continued opposition by several civil society organisations however, indicated that the move towards substantive transparency did not fully address the main accusations and concerns of public opinion (Agence Europe, 2015b). DG Trade continued publishing additional factsheets on the content of the agreement and provided additional online material explaining EU negotiating positions and approaches (European Commission, 2015a). DG Trade also organised a

\footnotetext{
${ }^{6}$ The Commission proposes a negotiating mandate, which the Council may then alter according to its own preferences and sensitivities before adopting the final mandate. While the Parliament does not formally have a role at this stage, it has informal influence through resolutions and inter-institutional agreements.

${ }^{7}$ The TTIP mandate declassification already proved to be a precedent for the Trade in Services Agreement, as these directives were also released while negotiations were ongoing (Council of the EU, 2015).
} 
public outreach event in June 2015, and provided a glossary of frequently used terms in policy documents and a reader's guide to TTIP negotiation texts (European Commission, 2015e, 2015f, 2015g). Providing these types of explanatory notes in layman's terms marks a change in the quality of the information provided and indicates a shift from access to documents to enhancing the consumption of already available information (European Parliament, 2016a).

The November 2014 Communication already hinted at the precedential value of TTIP in terms of public transparency (European Commission, 2014b). With the publication of the 'Trade for All' strategy in October 2015, DG Trade laid the groundwork for extending the TTIP transparency policy to all future and ongoing trade negotiations (European Commission, 2015b). Since then, the new strategy has been implemented mainly via the DG Trade website by proactively publishing documents on other ongoing trade agreements like the Economic Partnership Agreements, EU-Canada Comprehensive and Economic Trade Agreement, EU-Japan Free Trade Agreement, and Trade in Services Agreement, together with a database containing the meetings of the Trade Commissioner, the Commissioner cabinet members and the Director-General of DG Trade (European Commission, 2016a).

In conclusion, the Commission's paradigm shift for public transparency started in 2014. Over the course of the latter half of 2014 DG Trade moved from its initial strategy of transparency in existence to a proactive approach to transparency in substance. It did so by making EU position papers and negotiation texts available online, without waiting for any specific demand. Throughout 2015, DG Trade published additional texts in conjunction with explanatory notes, shifting the quality of the information from mere access to documents to access to information. Instead of waiting for specific access to documents requests, the Commission's current transparency policy for trade negotiations relies on increasing the depth of information provided and proactive online publication of a wide array of negotiation texts and supporting explanatory documents. Since the launch of the 'Trade for All' strategy in October 2015, DG Trade has been extending this type of proactive, in-depth transparency policy to other trade negotiations as well.

\subsection{Institutional Transparency}

The TTIP transparency policy has also changed the way the Commission behaves in its relationship with the other EU institutions. Since 2006, the Commission has the sole responsibility for communication with the Parliament at the start, during, and at the end of trade negotiations (European Union, 2006). This complicated the historically difficult and unstructured communication between Parliament and Council on trade policy even more, resulting in a very slowly changing mind-set within the Council regarding communication with Parliament after the Lisbon Treaty (Parliament official 2, interview, April 2016; Parliament official 4, interview, May 2016).

However, under the Commission's influence, small changes were introduced in the Council-Parliament relationship. From 2011 a limited number of INTA members was allowed by the Council to consult the final negotiation directives in secured reading rooms. Other MEPs only received the draft mandate-a Commission document-and had to rely on the Commission to provide an unofficial summary of the changes that the Council had made in the final, approved directives (Parliament official 2 and 3 , interview, April 2016). ${ }^{8}$ By openly supporting the Parliament's request to the Council for the release of those final directives before the end of negotiations, as well as calling for such a release in its draft directives for later trade negotiations, the Commission has sought to position itself as a pro-transparency actor, shifting the blame for perceived secrecy onto the Council and member states.

Commission-Parliament relations exist of four main channels: exchange of documents, monthly INTA Committee meetings, monitoring groups, and technical briefings. These are supplemented by informal contacts between administrators from DG Trade and the INTA secretariat, and bilateral contacts between DG Trade specialised units and political groups and MEP's offices (Parliament official 1, interview, March 2016). The most obvious change since 2013 has been widening the information provision from a limited number of MEPs in the INTA Committee to all MEPs. Since the commitment made by previous Trade Commissioner Karel De Gucht to consider specific arrangements for TTIP documents, access to documents has been extended from a core group of MEPs in the INTA Committee and US monitoring group to all MEPs (Council of the EU, 2013). Documents provided by DG Trade to the Parliament belong to one of three categories: 'EU Limited', 'EU Restricted', and 'consolidated negotiation texts', with sensitivity increasing respectively.

By spring 2014, DG Trade e-mailed 'EU Limited' documents to the INTA Committee secretariat, who then distributed them via e-mail to all INTA Members. Individualised, watermarked paper copies of documents marked 'EU Restricted' were initially exclusively available to a core group of MEPs. ${ }^{9}$ This core group exists of the INTA Chair and Vice-Chairs, INTA Group Coordinators, INTA Standing and Shadow Rapporteurs for the US, and Chairs and Rapporteurs of other committees involved in the US monitoring group (European Parliament, 2014a). ${ }^{10}$ Access to these 'EU Restricted' documents in a secure reading room, however, was extended to all MEPs from the

\footnotetext{
${ }^{8}$ The 2010 Framework Agreement confirmed the existing practice established by the 1995 Code of Conduct that the Commission would inform Parliament of the draft recommendations for the negotiating directives.

${ }^{9}$ Two individualised and watermarked paper copies were also sent to the INTA Secretariat.

10 This arrangement applies exclusively to the US monitoring group (see below).
} 
beginning of 2015. 'Consolidated negotiation texts' were available only to the core group of MEPs (European Commission, 2014b; European Parliament, 2015a; 2015d).

At the end of 2015 new arrangements for access to TTIP documents were put in place (European Parliament, 2015f; Malmström, 2015). These operational arrangements extended access of all documents to all MEPs, with rules varying between classifications (European Parliament, 2015f). All MEPs have access to individualized and watermarked copies of 'EU Limited' documents via an online system ('SharePoint'), with possibility to print. ${ }^{11}$ This IT tool is considered a pilot project for other negotiations as well, however at the time of writing it is used for TTIP documents only (Parliament official 2, interview, April 2016). ${ }^{12}$ Provisions for 'EU Restricted' remained the same. Finally, all MEPs got access to 'consolidated negotiation texts' in a secure reading room. By spring 2016, access to all documents was further extended to Members of national parliaments in reading rooms in Member State capitals-extending the width of transparency even further (European Commission, 2015c; European Parliament, 2015c, 2015d, 2016b).

Hence, access to TTIP documents has been extended from a select number of INTA Members to all MEPs and even national parliamentarians. The 'Trade for all' strategy now envisages extending these practices for similar negotiations as well. ${ }^{13}$ As these documents are TPC documents, the Commission also uses this channel of transparency to communicate information from its discussions with the Council to Parliament. The quasiautomatic nature in which the document transfer takes place, indicates the proactive strategy of the Commis- sion's information provision towards the Parliament. The 'EU Restricted' category has seen the largest increase, indicating that more MEPs have also gotten access to much more in-depth, sensitive information (Figure 1).

DG Trade has also shifted its efforts to enhance both the depth and the width of information exchange through the several meeting formats of the INTA Committee, including the monthly INTA meetings, US monitoring group, technical briefings, and informal briefing meetings between DG Trade and the INTA secretariat. These briefing meetings between INTA administrators and DG Trade unit for Resources, Information and Policy Coordination (Directorate $A$ ) take place before each INTA meeting, in addition to continuous e-mail and telephone contact. Since the start of the $8^{\text {th }}$ Parliamentary term (July 2014), high-level Commission representatives have spoken about TTIP in INTA Committee nine times. ${ }^{14}$ Yet, the bulk of Commission-Parliament interaction on TTIP has taken place informally. The full agenda and strict meeting schedule of the monthly INTA Committee meetings do not allow the Commission to fulfil its Treaty obligation to immediately and fully inform the Parliament (Commission official 4, interview, January 2016).

This informal interaction takes place in monitoring groups and technical briefings. Monitoring groups with specific geographical orientations were created in INTA in June 2011 (European Parliament, 2011). ${ }^{15}$ Members are the Standing Rapporteur-an INTA Member from the political group that was allocated the respective region through the D'Hondt method-and Shadow Standing Rapporteurs for the remaining political groups (Parliament official 3, interview, April 2016; Parliament offi-

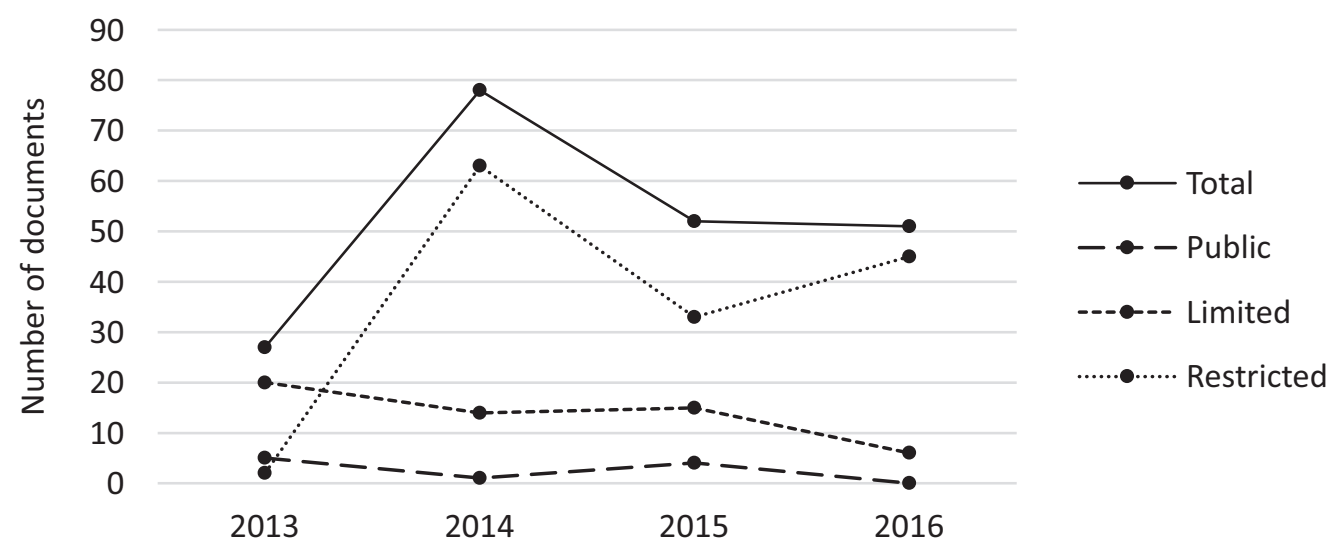

Figure 1. Number of TPC documents on TTIP, received by INTA. Source: Author's interview data.

\footnotetext{
11 INTA Secretariat staff and Group advisors have access to 'EU Limited' documents on a need-to-know basis. The limits of such 'need-to-know' were articulated in the document setting out the operational arrangements (European Parliament, 2015f; Malmström, 2015).

12 Documents for other trade negotiations go through INTA secretariat and are distributed by e-mail to interested INTA members (Parliament official 2, interview, April 2016).

13 Interestingly, all documents-even consolidated texts-relating to the Trade in Services Agreement are sent by the INTA secretariat to interested INTA MEPs via e-mail (Parliament official 3, interview, April 2016).

${ }^{14}$ Current Trade Commissioner Malmström has been in the INTA Committee to talk about TTIP five times and current TTIP chief negotiator Bercero three times.

15 The current rules are set out in the INTA General Principles regarding Standing Rapporteurs and Monitoring Groups for Negotiations and Implementation of International Trade Agreements (European Parliament, 2015e).
} 
cial 4, interview, May 2016; see also Coremans \& Meissner, 2017; European Parliament, 2017). ${ }^{16}$ During monitoring group meetings DG Trade briefs the MEPs of the latest developments in negotiations and puts a lot of effort in providing detailed explanations of technical aspects. This is then followed by questions from MEPs and direct discussion on issues they might bring up. The incamera quality of monitoring groups is considered important for exchanging confidential information, as the Commission uses monitoring groups for passing political messages on the state of play in external negotiations (Parliament official 2 and 3, interview, April 2016; Parliament official 4, interview, May 2016).

Following the regional organisation, the monitoring group for the US covers TTIP. Special arrangements are in place when the US monitoring group meets on TTIP. Towards the end of 2013, the INTA Committee decided to extend invitations for TTIP meetings to the Chair and Standing Rapporteurs of other opinion-giving Committees. This is currently a unique feature in INTA. ${ }^{17}$ During the electoral transition period mid-2014, special arrangements were made for the US monitoring group, to ensure continuity of the information exchange (European Parliament, 2014b). The EU Chief negotiator for TTIP briefs MEPs before and after each negotiation round in the US monitoring group. The pre-round briefing in the US monitoring group allows MEPs to send clear messages to the TTIP chief negotiator in DG Trade and makes the US monitoring group meetings more structured and detailed (Parliament official 4, interview, May 2016). This also means the US monitoring group meets more often than others, as those only meet once after negotiation rounds (Commission official 1, interview, November 2015). With 10 meetings and an average of 22 MEPs attending in 2015, compared to an average of 3 meetings and 3 MEPs attending for all other monitoring groups, the US monitoring group was by far the most popular monitoring group that year (Parliament official 4, interview, May 2016).

In addition to monitoring groups, DG Trade can ask the INTA secretariat to organise technical briefings with the members of the monitoring group (Commission official 1, interview, November 2015). These briefings go into depth about technical issues of a trade agreement. MEPs (or often their assistants in this case), political group advisors, and INTA secretariat administrators can ask questions to the DG Trade directly, which makes these technical briefings yet another way for DG Trade to provide in-depth information about ongoing trade negotiations (Commission official 4, interview, January 2016; Parliament official 3, interview, April 2016; Parliament official 4, interview, May 2016). On TTIP, 35 monitoring groups and 7 technical briefings took place from 2013 to 2016 (Parliament official 4, interview, May 2016).

All informal meeting formats discussed above, strengthen the MEP's and INTA staff's understanding of ongoing negotiations. DG Trade uses the meetings to give supplementary information, clarification and answers to questions that may have arisen after consulting negotiation documents. In addition, the informal nature of these exchanges also allows for orally communicating information that is not considered suitable to provide in written form. Hence, the informal communication practices between DG Trade and INTA serve to deepen the transparency in substance, compared to written communication and access to documents only. Extending the invitation to attend the US monitoring group to MEPs from other Committees-when covering TTIP matters-is also an indication of widening the institutional transparency beyond expanding institutional access to documents.

\subsection{Summarising the Findings}

The Commission's paradigm shift for public transparency started in 2014 when DG Trade moved from its initial strategy of transparency in existence to a proactive approach to transparency in substance. Throughout 2015, the quality of the information shifted from access to documents to access to information. Instead of waiting for specific access to documents requests, the Commission's current transparency policy for trade negotiations relies on increasing the depth of information provided and proactive online publication of a wide array of negotiation texts and supporting explanatory documents (Table 1). The 'Trade for All' strategy sets the scene for a spill-over of these changes to other trade negotiations.

The Commission has also shifted to a more proactive and in-depth communication strategy with the Parliament, mainly by extending its informal engagement with MEPs of the INTA Committee and sharing more indepth information about the substance of the TTIP agreement. By extending access to documents from a limited number of INTA Members to all MEPs, the institutional width of transparency has increased significantly (Table 1). Moving towards more transparency on these three dimensions has fostered a more stable working relationship between Commission and Parliament, enhanced the quality of exchanges in the INTA Committee and emphasised the role of the Commission as an interlocutor between Council and Parliament while positioning the transparency-minded Commission against a secretive Council.

\section{Conclusion}

This article has sought to explain how and why the Commission has developed a transparency policy for TTIP that goes beyond the legal minimum imposed by Treaty and case law or formal requirements enacted in institutional agreements. Assessing transparency from the supply-side revealed that shifting from a trans-

\footnotetext{
16 In addition, access is granted to political group advisers of INTA, assistants of INTA Members and substitutes, the INTA secretariat, the Legal Service, and the Policy Department. The Chair of the relevant Parliamentary Delegation for relations with the respective country is also invited.

17 At the time of writing, discussions to extend this practice to the Trade in Services Agreement monitoring group were ongoing.
} 
Table 1. Effect of TTIP on the three dimensions of transparency. Source: Author's own data.

\begin{tabular}{|c|c|c|}
\hline & Public transparency & Institutional transparency \\
\hline Depth & $\begin{array}{l}\text { Communications on EU decision-making } \\
\text { processes } \\
\text { Lists of institutional documents } \\
\text { EU position papers } \\
\text { Negotiation and legal texts }\end{array}$ & $\begin{array}{l}\text { Final negotiation directives } \\
\text { Increased provision of 'EU restricted' documents } \\
\text { Oral information through informal monitoring } \\
\quad \text { groups, technical briefings, staff-level meetings }\end{array}$ \\
\hline Width & $\begin{array}{l}\text { Online public repositories } \\
\text { Social media } \\
\text { Glossary and reader's guide } \\
\text { Explanatory texts } \\
\text { Factsheets }\end{array}$ & $\begin{array}{l}\text { Access to all types of documents for all MEPs } \\
\text { (and national MPs) } \\
\text { Extended number of participants in US } \\
\text { monitoring group }\end{array}$ \\
\hline Manner of provision & $\begin{array}{l}\text { From individual access to documents to: } \\
\text { - Automatic online publications } \\
\text { - Public outreach events }\end{array}$ & $\begin{array}{l}\text { Automated transfer of TPC documents through } \\
\text { dedicated IT systems } \\
\text { Organisation of informal communication channels }\end{array}$ \\
\hline
\end{tabular}

parency policy based on access to documents to one fostering consumption of information is beneficial for the Commission as well. By reducing information asymmetry, the Commission enhances its external negotiation effectiveness-i.e. concluding an international trade agreement, rather than compromising its interinstitutional bargaining power.

Throughout the course of the TTIP negotiations the Commission has introduced a public transparency policy aimed at improving consumption of information. The proactive nature of DG Trade's transparency policy for TTIP-going beyond individual access to document requests-aids the Commission's public profiling as a transparent actor as opposed to a secretive Council. This became particularly clear in its steady pressure on the Council to release the negotiation mandates for trade agreements, as well as the repeated statements by Commissioner Malmström urging Member States to take up responsibility in communication with the European public. The release of the negotiation mandate also shows how institutional and public transparency are linked: with the public availability of the negotiation mandate for TTIP, the institutional transparency also widened as MEPs that did not have access to those texts before could now access them freely.

On the inter-institutional level, the Commission has taken on the role of interlocutor to facilitate the weak link between Council and Parliament in trade policy, and is investing substantial resources in developing a stable base for information exchange with the Parliament. By automatically transferring TPC documents to the INTA Committee, extending the practice of informal technical meetings (as they were in place with the Council) to interactions with INTA, as well as supporting the Parliament's demands for releasing negotiation directives, the Commission has shifted from a reactive to a proactive actor in transparency. By supplementing expanded access to documents with in-depth explanations of current issues in the monitoring groups and technical briefings, the Com- mission has developed a transparency policy geared towards consumption of information.

In terms of democratisation and legitimacy concerns, the Commission's focus on the consumption of information may reduce the perceived democratic deficit in EU trade policy: enhancing the quality of the informationcompared to a quantitative increase in the number of documents only-strengthens the link between transparency and legitimacy of decision-making outcomes. By focusing in particular on institutional transparency, this link can be strengthened while at the same time shielding internal decision-making processes. Yet questions remain as to the selection of information that is proactively provided and the choice of means through which this provision takes place: what determines which documents are subject to public or institutional transparency, and which media or institutional channels are used to communicate the information? For instance, the rise in the number of restricted documents available to the Parliament may indicate an attempt to balance the extent of the reduction of information asymmetry with protecting a necessary level of confidentiality. In other words, how does the Commission balance the benefits and costs of lowering institutional information asymmetries?

This article has offered an alternative view of the reasoning behind the increasing transparency of EU trade policy by shifting the implicit conceptualisation of the Commission-on-the-defensive, to one of a proactive supplier of transparency-even in absence of a specific demand. Throughout the TTIP negotiations the Commission has gone beyond individual access to documents requests and is proactively providing in-depth transparency to a broader public and institutional audience. This shift, as well as the importance placed by DG Trade on communication with the Parliament's INTA Committee, are indications of the benefits related to lowering information asymmetry for the Commission as an effective external negotiator. 


\section{Acknowledgments}

I would like to thank the editors of this thematic issue for their remarks and suggestions, which helped shape the article as it currently stands. While their identity will remain anonymous, I extend my gratitude to the interviewees for sharing their valuable time and insights. Any errors remain the sole responsibility of the author. The research was funded by a PhD Fellowship of the Research Foundation Flanders.

\section{Conflict of Interests}

The author declares no conflict of interests.

\section{References}

Abazi, V. (2016). European Parliamentary oversight behind closed doors. Cambridge Journal of International and Comparative Law, 5(1), 31-49.

Abazi, V., \& Adriaensen, J. (2017). Allies in transparency? Parliamentary, judicial and administrative interplays in the EU's international negotiations. Politics \& Governance, 5(3), 75-86.

Abazi, V., \& Tauschinsky, E. (2015). Reasons of control and trust: Grounding the public need for transparency in the European Union. Utrecht Law Review, 11(2), 78-90.

Adriaensen, J., \& Coremans, E. (2017). Controlling covert integration in EU politics. In P. Bursens, C. De Landtsheer, L. Braeckmans, \& B. Segaert (Eds.), Complex political decision-making. Leadership, legitimacy and communication (pp. 77-93). Abingdon: Routledge.

Agence Europe. (2014a). Warnings of growing hostility on TTIP. Bulletin Quotidien Europe 11029. Retrieved from http://www.agenceeurope.com

Agence Europe. (2014b). Four actions for greater transparency of TTIP negotiations. Bulletin Quotidien Europe 11204. Retrieved from http://www.agence europe.com

Agence Europe. (2015a). New stage in European initiative for TTIP transparency. Bulletin Quotidien Europe 11225. Retrieved from http://www.agence europe.com

Agence Europe. (2015b). European civil society warns of TTIP dangers. Bulletin Quotidien Europe 11246. Retrieved from http://www.agenceeurope.com

Bjurulf, B., \& Elgström, O. (2004). Negotiating transparency: The role of institutions. Journal of Common Market Studies, 42(2), 249-269.

Brandsma, G. J. (2012). The effect of information on oversight: The European Parliament's response to increasing information on comitology decision-making. International Review of Administrative Sciences, 78(1), 74-92. doi:10.1177/0020852311429756

Coremans, E., \& Kerremans, B. (2017). Agents as information asymmetry managers in EU trade policy-making. In T. Delreux \& J. Adriaensen (Eds.), The principal- agent model and the European Union. Basingstoke: Palgrave Macmillan. Book in preparation.

Coremans, E., \& Meissner, K. L. (2017). Putting power into practice: Capacity-building and the European Parliament's role in EU trade negotiations. Paper presented at workshop "The new politics of EU trade policy: (potential) consequences of parliamentarisation and politicisation", University of Gothenburg, Sweden.

Council of the EU. (2013). Summary record of the meeting of the European Parliament Committee on International Trade (INTA), Brussels, 27-28 November 2013 (17185/13). Brussels: Council of the EU.

Council of the EU. (2014). Directives for the negotiation on the Transatlantic Trade and Investment Partnership between the European Union and the United States of America (11103/13 DCL 1). Brussels: Council of the EU.

Council of the EU. (2015). Draft Directives for the negotiation of a plurilateral agreement on trade in services (6891/13 ADD 1 DCL 1). Brussels: Council of the EU.

Cremona, M. (2015). Guest editorial: Negotiating the Transatlantic Trade and Investment Partnership (TTIP). Common Market Law Review, 52, 351-362.

Cross, J. P. (2014). The seen and the unseen in legislative politics: Explaining censorship in the Council of Ministers of the European Union. Journal of European Public Policy, 21(2), 268-285.

Cross, J. P., \& Bølstad, J. (2015). Openness and censorship in the European Union: An interrupted time series analysis. European Union Politics, 16(2), 216-240.

Curtin, D. (2014). Challenging executive dominance in European democracy. The Modern Law Review, 77(1), $1-32$.

Curtin, D., \& Meijer, A. (2006). Does transparency strengthen legitimacy? Information Policy, 11, 109-122.

De Fine Licht, J. (2014). Transparency actually: How transparency affects public perceptions of political. European Political Science Review, 6(2), 309-330.

Devuyst, Y. (2013). European Union law and practice in the negotiation and conclusion of international trade agreements. Journal of International Business \& Law, 12(2), 259-316.

Devuyst, Y. (2015). European Union trade policy after the Lisbon Treaty: The Community method at work. In N. Witzleb, A. Martinez Arranz, \& P. Winand (Eds.), The European Union and global engagement. Institutions, policies and challenges (pp. 138-158). Cheltenham: Edward Elgar Publishing.

Dür, A., \& Matteo, G. (2014). Public opinion and interest group influence: How citizen groups derailed the Anti-Counterfeiting Trade Agreement. Journal of European Public Policy, 21(8), 1199-1217.

Egeberg, M., Gornitzka, A.., \& Trondal, J. (2014). A not so technocratic executive? Everyday interaction between the European Parliament and the Commission. West European Politics, 37(1), 1-18. 
Eibauer, J. (2012). Blessing or curse? The effects of transparency on the European Commission's success at the international ACTA negotiations (Working paper no. 14). Berlin: Center for International Political Economy.

European Commission. (2013). Arrangements on TTIP negotiation documents. Brussels: European Commission.

European Commission. (2014a). The Transatlantic Trade and Investment Partnership (TTIP): We're listening and engaging. Brussels: European Commission.

European Commission. (2014b). Communication to the Commission concerning transparency in TTIP negotiations (C(2014) 9052 final). Strasbourg: European Commission

European Commission. (2014c). Comments of the Commission on the European Ombudsman's own-initiative inquiry (OI/10/2014/RA). Brussels: European Commission.

European Commission. (2015a). The top 10 myths about TTIP: Separating fact from fiction. Luxembourg: Publications Office of the European Union.

European Commission. (2015b). Trade for all: Towards a more responsible trade and investment policy. Luxembourg: Publications Office of the European Union.

European Commission. (2015c). TTIP: Possible steps to facilitate the accessibility of EU Member States to certain classified TTIP documents. Brussels: European Commission.

European Commission. (2015d). Follow-up reply from the European Commission to the Ombudsman's closing decision in OI/10/2014/RA on transparency and public participation in the TTIP negotiations (OI/10/2014/RA). Brussels: European Commission.

European Commission. (2015e). European trade policy day. Brussels: European Commission.

European Commission. (2015f). Glossary. Brussels: European Commission.

European Commission. (2015g). TTIP negotiating texts. A reader's guide for the list of TTIP documents published on 7 January 2015. Brussels: European Commission.

European Commission. (2016a). Reply to application for access to documents (GestDem No 2015/1011). Brussels: European Commission.

European Commission. (2016b). List of documents sent to the Council of the EU and the European Parliament. Brussels: European Commission.

European Ombudsman. (2015a). Decision of the European Ombudsman closing her own-initiative inquiry OI/10/2014/RA concerning the European Commission (OI/10/2014/RA). Brussels: European Ombudsman.

European Ombudsman. (2015b). Decision of the European Ombudsman closing her own-initiative inquiry OI/11/2014/RA concerning the Council of the European Union (OI/11/2014/RA). Brussels: European Ombudsman.
European Parliament. (2011). Coordinators' minutes of Tuesday 21 June 2011 (in camera) (INTA(2011) 0621_2). Brussels: European Parliament.

European Parliament. (2014a). Answer given by Mr De Gucht on behalf of the Commission to parliamentary question E-002830/2014 (OJ 2014/C 326). Brussels: European Parliament.

European Parliament. (2014b). Minutes of meeting of 1 April 2014 (INTA_PV(2014)0401_1). Brussels: European Parliament.

European Parliament. (2015a). Comparative study on access to documents (and confidentiality rules) in international trade negotiations (EP/EXPO/B/INTA/FWC/ 2013-08/lot7/06). Brussels: European Parliament.

European Parliament. (2015b). Comments from the European Parliament concerning the European Ombudsman's own-initiative inquiry OI/6/2013/KM (E2014190064). Brussels: European Parliament.

European Parliament. (2015c). Answer given by Ms Malmström on behalf of the Commission to parliamentary question E-014341/2015. European Parliament. Retrieved from http://www.europarl.europa. eu/sides/getDoc.do?type $=$ WQ\& reference $=E-2015-01$ 4341\&language $=\mathrm{EN}$

European Parliament. (2015d). Reply to parliamentary question E-015494/2015. European Parliament. Retrieved from http://www.europarl.europa.eu/ sides/getDoc.do?type $=$ WQ\& reference $=E-2015-0154$ 94\&language $=\mathrm{EN}$

European Parliament. (2015e). Answer given by Ms Malmström on behalf of the Commission to parliamentary question E-003185/2015. European Parliament. Retrieved from http://www.europarl.europa. eu/sides/getDoc.do?pubRef=-\%2f\%2fEP\%2f\%2fTEXT \%2bWQ\%2bE-2015-003185\%2b0\%2bDOC\%2bXML\% $2 \mathrm{bV} 0 \% 2 \mathrm{f} \% 2 \mathrm{fEN}$ \&language $=\mathrm{EN}$

European Parliament. (2015d). Minutes of meeting of 21 and 22 January 2015 (INTA_PV(2015)0121_1). Brussels: European Parliament.

European Parliament. (2015e). Minutes of meeting of 23 and 24 February 2015 (INTA_PV(2015)0223_1). Brussels: European Parliament.

European Parliament. (2015f). Access to TTIP-related documents-Comprehensive agreement on operational arrangements between the INTA Committee and DG TRADE (Ares(2015)5740097). Brussels: European Parliament.

European Parliament. (2016a). Answer given by Ms Malmström on behalf of the Commission to Parliamentary Question E-003185-15. European Parliament. Retrieved from http://www.europarl.europa. eu/sides/getAllAnswers.do? reference $=\mathrm{E}-2015-00318$ $5 \&$ language $=\mathrm{EN}$

European Parliament. (2016b). Answer given by Ms Malmström on behalf of the Commission to parliamentary question E-001371/2016. European Parliament. Retrieved from http://www.europarl.europa. eu/sides/getDoc.do?type $=W Q \&$ reference $=E-2016-00$ 
1371\&language $=\mathrm{EN}$

European Parliament. (March, 2017). INTA Standing and Shadow Rapporteurs. European Parliament. Retrieved from https://polcms.secure.europarl.europa. eu/cmsdata/upload/c66c582f-3d7d-4893-92fa-496c 4e4c4453/inta-standing-and-shadow-rapporteurs.pdf

European Union. (2006). Framework agreement on relations between the European Parliament and the European Commission (OJ 2006/C 117 E/02). Brussels: European Union.

Gheyle, N., \& De Ville, F. (2017). How much is enough? Explaining the continuous transparency conflict in TTIP. Politics \& Governance, 5(3), 16-28.

Hillebrandt, M. Z., \& Abazi, V. (2015). The legal limits to confidential negotiations: Recent case law developments in Council transparency: Access Info Europe and In 't Veld. Common Market Law Review, 52, 825-846.

Hillebrandt, M. Z., Curtin, D., \& Meijer, A. (2014). Transparency in the Council of Ministers of the EU: An institutional approach. European Law Journal, 20(1), 1-20.

Hillebrandt, M. Z., \& Novak, S. (2016). “Integration without transparency"? Reliance on the space to think in the European Council and Council. Journal of European Integration, 38(5), 1-14.

Jančić, D. (2016). The role of the European Parliament and the US Congress in shaping transatlantic relations: TTIP, NSA surveillance, and CIA renditions. Journal of Common Market Studies, 54(4), 896-912.

Kleimann, D. (2011). Taking stock: EU Common commercial policy in the Lisbon era (Working paper no. 346). Brussels: Centre for European Policy Studies.

Leino, P. (2014). Transparency, participation and EU institutional practice: An inquiry into the limits of the "Widest Possible" (Working paper no. 2014/03). Florence: European University Institute.

Malmström, C. (2015). Letter to chairman (Ares(2015) 5522083). Brussels: European Commission.

Meijer, A. (2013). Understanding the complex dynamics of transparency. Public Administration Review, 73(3), 429-439.
Meijer, A. (2015). Government transparency in historical perspective: From the Ancient Regime to open data in the Netherlands. International Journal of Public Administration, 38(3), 189-199.

Meijer, A., Curtin, D., \& Hillebrandt, M. Z. (2012). Open government: Connecting vision and voice. International Review of Administrative Sciences, 78(1), 10-29.

Meissner, K. L. (2016). Democratizing EU external relations: The European Parliament's informal role in SWIFT, ACTA, and TTIP. European Foreign Affairs Review, 22(2), 269-288.

Mitchell, R. B. (1998). Sources of transparency: Information systems in international regimes. International Studies Quarterly, 42(1), 109-130.

Mungengová, J. (2016). The EU enhanced transparency in TTIP: A successful shift of paradigm. Cerim. Retrieved from https://cerim.blogactiv.eu/ 2016/03/01/the-eu-enhanced-transparency-in-ttipa-successful-shift-of-paradigm

Naurin, D. (2007). Backstage behavior? Lobbyists in public and private settings in Sweden and the European Union. Comparative Politics, 39(2), 209-228.

Ostry, S. (2004). External transparency: The policy process at the national level of the two level game. In M. Moore (Ed.), Doha and beyond: The future of the multilateral trading system (pp. 94-114). Cambridge: Cambridge University Press.

Pozen, D. E. (2010). Deep secrecy. Stanford Law Review, 62(2), 257-339.

Ripoll Servent, A., \& Busby, A. (2013). Introduction: Agency and influence inside the EU institutions. European Integration Online Papers, 17(1), 1-22.

Rosén, G. (2016). A match made in heaven? Explaining patterns of cooperation between the Commission and the European Parliament. Journal of European Integration, 38(4), 409-424.

Rosén, G., \& Stie, A. E. (2017). Not worth the net worth? The democratic dilemmas of privileged access to information. Politics and Governance, 5(3), 51-61.

Winham, G. R. (1979). Practitioners' views of international negotiation. World Politics, 32(1), 111-135.

\section{About the Author}

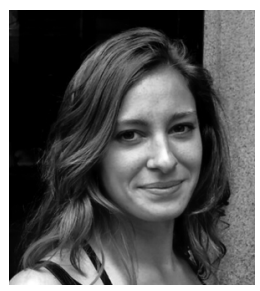

Evelyn Coremans is a PhD researcher at the Leuven Institute for International and European Studies (LINES) of the KU Leuven. Her research is funded by the Research Foundation Flanders (FWO) and is centred around informal decision-making procedures in EU policy-making with a particular focus on trade policy and the TTIP. 